(\#88, December 1984) on that task featured such challenges as "look for another fiche reader in which the bulb has not burned out" and "climb five flights of stairs thinking of it as exercise." His world-famous treatise on "The Storage and Care of Librarians" was cited in an earlier column (April 1989). For all they have done to promote the cause of library humor, Cum Notis Variorum, Skillin Q. Fowlstrunker, and Ann P. Basart deserve special commendation.

The final example of humor from the music library is from a short series on the place, and placement, of the pencil sharpener in libraries that appeared in The Lantern's Core, from the Northwestern University Library in 1972. The final contribution in that multi-part series from Stephen Fry on "A Music Library Pencil Sharp- ener" (December 13, 1972) confirms part of my initial hypothesis that the right brain/left brain syndrome may be behind the deviant nature of humor in the music library. His note describes a gray Apsco "Giant" type III-A sharpener and the problems encountered in providing effective access to it when new stacks were added. The ultimate solution was to "rotate the sharpener base 180 degrees (along an East-West axis), and then rotate the pencil shavings compartment, which holds the rotary head, 180 degrees (along a North-South axis)....It is now especially handy for left-handed people [Fry noted].... and this seems to be a great drawing feature of our library.... We invite left-handed people who cannot elsewhere find suitable machines to sharpen their pencils at the Music Library."

\title{
A library-sponsored tutorial program
}

\author{
By Susan Deese
}

Director, Center for Academic Program Support

University of New Mexico

The Center for Academic Program Support (CAPS), a comprehensive tutorial center, has been a department within the University of New Mexico General Library since 1980. The program, originally called the Skills Center, was established in 1979 as the academic support unit of a comprehensive remedial program. During 1979-1980, the Center was housed in the library but was not part of the library administratively. Funding was provided through an instructional budget from the Office of the Provost.

Since that time, the Center has expanded its support services to provide assistance to all undergraduate students and to graduate students enrolled in selected statistics courses. Credit library courses are offered through the Center. Library 110 is a two-credit course in learning skills which emphasizes the relationship between traditional study skills and learning theory. Library 111 is a twocredit course in library skills which emphasizes a search strategy approach to the use of library tools. Library 112 is a one-credit course in which students combine skills from Library 111 with paperwriting skills to produce a research paper.

The director of the Center is the only member of the library faculty who does not have a Master of Library Science degree. The director's terminal degree is a Doctor of Philosophy in Adult Education. When the director completed the Ph.D. in 1984 , the library faculty members voted to accept the di- rector into the faculty. Until that time, the director had been a member of the administrative staff reporting to the assistant dean for public services but had not been a member of the library faculty. Currently, the Center director is a member of the Council of Department Heads which serves as the library management team.

Funds for the program are provided to the library in a separate instructional budget from the Office of the vice president for academic affairs (formerly the Office of the Provost). In 1985 the undergraduate student leaders decided to terminate their attempts at sponsoring a tutorial program and decided to allocate student fees to the Center for the purpose of providing assistance to all undergraduates. In 1988 the leaders of the Graduate Student Association voted to allocate funds to the Center for the purpose of providing tutorial assistance to graduate students enrolled in selected graduate level statistics courses.

More than 5,000 students (approximately onethird of the undergraduate population) came to the Center during 1987-1988. More than 19,500 contacts were made with those students for a total of approximately 13,000 contact hours (actual amount of time spent by students at the Center). In addition to the director, the staff includes an associate director, an assistant director, a coordinator of special programs, an administrative secretary, a weekend and evening supervisor, and approxi- 
mately 70 student employees (graduate assistants, tutors, receptionists, and data entry clerks). The Center's professional staff members participate in a number of university programs including student recruitment, freshman orientation, and new faculty orientation. The director serves on several university committees including the Committee for Disabled Students and the Adult Reentry Committee.

Though the instructional budget for the Center is separate from the general funds allocated to the General Library, library policies and procedures apply to the expenditure of all funds. Student and staff employment is handled by the library's personnel specialist. The Center maintains a small catalogued collection of study skills materials which are selected by the director. Some Center staff members have been trained as substitutes on the General Reference and Government Publications Reference desks. A description of Center services is included in most library tours for undergraduate students. Plans for the future include term paper workshops conducted by Center staff and Reference Department librarians, graduate level library skills courses, and expanded paperwriting services offered through the Center's Writing Lab. The director is currently chair of the Library Instruction Committee which is composed of representatives from each public service area and branch library in the General Library system. The Center has become an integral part of the General Library.

The following assertions can be made to support the presence of the tutorial program in the library: the General Library is the only college on campus mandated to serve the needs of all students; out-ofclassroom learning is the hallmark of the library learning experience; and the Center's services and policies are based upon a philosophy of adult education which is consistent with the library's philosophy of developing lifelong learners.

Though often referred to as the "heart" of the university, libraries are too often viewed as being adjunct to the educational process. This may be due in part to a lack of understanding on the part of teaching faculty concerning the complexities of library operations and reference services. For the most part, members of the teaching faculty understand the complexities of student learning better than they understand the complexities of library services. Tutorial assistance as a library service provides a tangible link between librarians and teaching faculty.

In Alliance for Excellence, the following recommendations are made:

-We recommend that libraries accept their central role in the Learning Society as valid learning centers. Further, we recommend that these centers be staffed with user-oriented professionals who not only understand community needs but also know learning resources. These "learners" advisers would help patrons to gain the information and skills to function successfully in the Learning Society. ${ }^{1}$

- College and university libraries should be staffed with strong advisers to lead students toward advanced learning skills. ${ }^{2}$

Tutorial assistance programs are one means of implementing these recommendations.

${ }^{1}$ U.S. Department of Education, Alliance for Excellence: Librarians Respond to a Nation at Risk (Washington D.C.: Government Printing Office, 1984), 28.

${ }^{2}$ Alliance for Excellence, 29.

\section{Letter}

\section{InfoTrac}

\section{To the Editor:}

We were pleased to find "Users' Reaction to InfoTrac in an Undergraduate Library" by Ellen P. Flynn in the January 1989 issue. Palo Alto College recently conducted a user survey on Info'Trac using the same questionnaire. Our results were very similar. The 39 users who responded were 35 students, 3 faculty members, and 3 business persons (two students doubled as business persons). We received 31 overall positive responses, no negative remarks, and 8 no comments. All respondents gave InfoTrac high ratings in the survey. Thanks to Ellen Flynn and $C \& R L$ News for validating the results of our survey.-Camille Fiorillo, Librarian, Palo Alto College, San Antonio, Texas.

\section{Applications invited for C\&RL editor}

Nominations and applications are invited for the position of editor of College of Research Libraries. The editor is appointed for a three-year term which may be renewed for an additional three years. Applicants must be members of ALA and ACRL. Qualifications include experience in academic libraries, evidence of research and editing activity, and a broad knowledge of the issues confronting academic libraries. A small honorarium for the editor and funding arrangements for editorial assistance are available. Nominations or resumes with names of three references may be sent to: C. Brigid Welch, Chair, College and Research Libraries Search Committee, Central University Library, C-075-R, University of California, San Diego, La Jolla, CA 92093. The deadline for applications is May 1, 1989. 